Al-Fikra: Jurnal Ilmiah Keislaman, Vol. 5, No. 2, Juli-Desember 2006

\section{MODEL PENGEMBANGAN PENDIDIKAN TINGGI: \\ TELAAH ATAS EKSISTENSI DAN TANTANGAN PTAI DAN PERUBAHAN IAIN MENJADI UIN}

\author{
Ziyadul Kamal \\ Fakultas Tarbiyah dan Keguruan UIN Suska Riau
}

\section{Abstract}

Model of Higher Education Development: A Study on the Existence and Challenge of PTAI and the Change of IAIN to UIN : The rationale behind change of the State Institute for Islamic Studies (LAIN) to the State Islamic University (UIN) is that Islam makes no discrimination between religious knowledge and general knowledge. The change of this status actually gives UIN a broader mandate compared to IAIN, that is, providing the community at large with the knowledge of Islam. This is in line with the new paradigm in higher education that has been formulated in national and international levels of education which, at the same time, studies the existence, opportunity and option being offered to develop itself to become a competitive bigher education institution. UIN is in fact different from other general higher education institutions and even different from other Islamic higher education institutions. UIN should be able to relate its teacbing materials to Islamic messages so that it is expected to produce Muslim scholars who possess two areas of knowledge, knowledge in science and technology and knowledge in the field of Islamic perspectives.

Keywords: IAIN, UIN, Islamic Higher Education Institutions.

\section{Pendahuluan}

Kajian mengenai Perguruan Tinggi di Indonesia menemukan momentumnya ketika terjadi krisis moneter yang diikuti dengan krisis dalam bidang ekonomi, politik dan sosial. Krisis ini selain menimbulkan keprihatinan mendalam tentang meningkatnya drop out rate di kalangan mahasiswa, juga menyebabkan kemerosotan efektivitas dan efisiensi Perguruan Tinggi dalam menghasilkan mahasiswa dan lulusan yang memiliki competitive advantage atau daya
Ziyadul Kamal, MODEL PENGEMBANGAN PERGURUAN TINGGI... saing yang handal dan tangguh dalam menghadapi dunia globalisasi yang penuh tantangan.

Pengembangan Perguruan Tinggi, khususnya Perguruan Tinggi Agama Islam (PTAI) sebagai bagian integral dari sistem pendidikan nasional harus dilihat dari sudut pandang perubahan yang terjadi begitu cepat. Menjadikan PTAI sebagai universitas tidak harus menjadi sebuah solusi karena PTAI mempunyai sejarah tersendiri (their own history) dan eksistensi tersendiri dibandingkan dengan Universitas yang menawarkan prodi "non agama". PTAI, baik yang berstatus negeri atau swasta saat ini juga telah terbawa dalam arus industrialisasi jasa pendidikan.

Pengembangan PTAI, termasuk didalamnya IAIN harus dilihat dari sudut pandang dalam konteks perubahan baik pada tingkat konsep dan paradigma perubahan Perguruan Tinggi. Selain itu, pengembangan PTAI, khususnya kecenderungan IAIN menjadi UIN harus pula mempertimbangkan perubahan dan transisi dalam bidang sosial, ekonomi dan politik nasional serta global.

Ide utama mengubah status perguruan tinggi ini adalah bahwasanya dalam Islam tidak ada pembedaan antara ilmu agama dengan ilmu sekuler. Tetapi perubahan status ini sebenarnya memberikan Universitas Islam Negeri mandat yang lebih besar dibandingkan IAIN terdahulu, yakni memberikan pemahaman kepada khalayak ramai mengenai apa itu ilmu Islam.

Tulisan ini mencoba mengkaji eksistensi serta perubahanperubahan yang dapat ditempuh oleh PTAI khususnya IAIN dalam perspektif paradigma baru Perguruan Tinggi yang telah dirumuskan baik pada tingkat pendidikan nasional maupun internasional, selain itu juga ditawarkan sejumlah peluang dan alternatif yang dapat ditempuh oleh PTAI untuk mengembangkan dirinya menjadi Perguruan Tinggi yang dapat memberikan competitive advantage kepada mahasiswanya.

\section{Prospek dan Pengembangan PTAI}


A1-Fikra: Jurnal Ilmiah Keislaman, Vol. 5, No. 2, Juli-Desember 2006

Untuk mengetahui prospek PTAI, harus diketahui terlebih dahulu pengertian prospek ${ }^{1}$. Jika prospek adalah jumlah mahasiswa (sebagai pendukung utama keberadaan PTAI) maka sangat mungkin dalam 5-10 tahun ke depan prospek tersebut masih ada. Jika yang dimaksud dengan prospek adalah relevansi, maka harus didiskusikan secara panjang lebar karena sangat mungkin Program Studi (Prodi) yang ditawarkan PTAI mulai kehilangan relevansi atau kehilangan peminat sehingga harus dilakukan kompromi akademik dalam arti kehilangan prospek.

Aspek persaingan sehat menuju keunggulan kompetitif PTAI, berarti bahwa PTAI harus secara terus menerus melakukan dinamisasi dalam berbagai aktivitas kelembagaannya seperti upaya pencanangan PTAI sebagai Perguruan Tinggi atau Universitas Riset. Tantangan dalam persaingan ini dimanifestasikan oleh PTAI dengan usaha untuk mencapai standar mutu dengan melakukan dinamisasi yang meliputi aspek akademik, kelembagaan, kualifikasi tenaga kependidikan, penelitian, pengabdian kepada masyarakat, kerjasama serta publikasi karya ilmiah.

Adanya kenyataan mengenai realitas industrialisasi pendidikan tinggi selain menyebabkan kesulitan aspek input mahasiswa baru, juga mengancam keberadaan PTAI secara kelembagaan. Oleh karena itu diperlukan suatu cara pandang baru yang rasional, ke arah akselerasi pengembangan PTAI ke depan, baik oleh lembaga atau institusi yang berwenang.

Merger di antara PTAI juga dapat dilakukan sebagai upaya pengembangan untuk kemajuan bersama dengan landasan kesamaan ideologi, visi, misi atau bahkan karena kesamaan motif dalam bingkai industri jasa pendidikan. Di sinilah era keterbukaan manajemen termasuk lembaga penyelenggara pendidikan tinggi swasta oleh yayasan-yayasan tertentu, dimungkinkan untuk mempertemukan kekuatan sinergi.

${ }^{1}$ Masykur Wiratmo, "Prospek PTAI di Indonesia (Mengamati Kecendrungan Perubahan ke Arah UIN)" (Jakarta: Swara Ditpertais, 2005), No. 24 Th, III, 03 Februari 2005, hlm. 2.
Ziyadul Kamal, MODEL PENGEMBANGAN PERGURUAN TINGGI..

\section{Tantangan Perguruan Tinggi Islam (PTAI)}

Saat ini sebagian besar PTAI menghadapi kendala utama yang sama yaitu menurunnya input mahasiswa di PTAI. Hal tersebut ditengarai karena kurangnya minat mereka untuk belajar di PTAI. Asumsinya, PTAI tidak bisa memberikan prospek masa depan yang baik. Ada dua sebab mengapa demikian; pertama, sikap inferioritas dari civitas akademika; kedua, perlakuan administratif dari pengguna lulusan PTAI yang sering memperlakukan tidak adil terhadap lulusan PTAI. Kondisi ini, diperparah dengan tidak diimbanginya proses pembelajaran di PTAI yang lebih baik.

Dalam konteks tersebut, sosialisasi visi dan misi PTAI sangat penting, terutama bagi civitas akademika. Berhasil tidaknya suatu PTAI sangat terkait dengan visi dan misi lembaganya. Jika visi dan misinya jelas, maka eksistensi PTAI akan dapat dipertahankan dan dikembangkan, begitu juga sebaliknya. Karena itu, visi dan misi PTAI harus dipahami dan diketahui secara terbuka.

PTAI pada hakekatnya adalah lembaga pendidikan yang mengembangkan konsep Islam sebagai nilai dan sekaligus sumber ilmu yang mencakup ${ }^{2}$ :

1. Nilai Benar, tidak akan bertentangan secara epistemologis dalam kaitannya dengan kerja nalar maupun dalam kenyataan praktek kehidupan

2. Nilai Baik, tidak akan kontra-produktif dalam seluruh tatanan kehidupan nyata

3. Nilai Indah, berbanding lurus dengan rasa estetika manusia yang bersifat universal

4. Nilai Religiousitas, berupa perasaan "dekat dengan Tuhan" yang merahmati (mengayomi, melindungi, mengasihi, menyayangi), memberkahi dan menyelamatkan (terutama yang bersifat eskatologis atau keakhiratan/kehidupan setelah mati.

Dengan menjalankan konsep tersebut, maka institusi universitas cocok untuk pengembangan PTAI ke depan, sehingga semua ilmu dapat dihargai seimbang untuk dikembangkan, tanpa

${ }^{2}$ Ibid, hlm. 4. 
Al-Fikra: Jurnal Ilmiah Keislaman, Vol. 5, No. 2, Juli-Desember 2006 ada perbedaan antara ilmu agama (ilmu akhirat, ilmu ukhrawi) dan ilmu umum (ilmu dunia/ilmu sekuler).

\section{Paradigma Baru Perguruan Tinggi Indonesia}

Konsep "Paradigma Baru"3 bagi Perguruan Tinggi di Indonesia merupakan sebuah keharusan. Paradigma baru tersebut, mau tidak mau, melibatkan reformasi besar yang mencakup perubahan kebijakan yang lebih terbuka, transparan dan akuntabel. Dengan reformasi dan perubahan Perguruan Tinggi dapat melayani kebutuhan yang lebih beragam bagi lebih banyak orang dengan kandungan pendidikan (contents), metode, dan penyampaian pendidikan berdasarkan jenis dan bentuk-bentuk baru hubungan dengan masyarakat dan sektor-sektor masyarakat lebih luas.

Paradigma baru Perguruan Tinggi yang sekarang ini di Indonesia menjadi kerangka dan landasan pengembangan Perguruan Tinggi merupakan hasil dari pembahasan dan perumusan yang telah dilakukan sejak waktu yang lama baik pada tingkat nasional maupun internasional. Sekali lagi, IAIN sebagai bagian integral dari sistem pendidikan nasional juga tidak bisa melepaskan diri dari perumusan-perumusan yang berkembang dari waktu ke waktu tersebut.

Kajian ulang terhadap kinerja Perguruan Tinggi secara komprehensif, menghasilkan pemikiran dan konsep baru tentang pengembangan Perguruan Tinggi dapat dilihat pada kerangka yang diajukan oleh D.A Tisna Amijaya4. Sebelum memberikan kerangka pengembangan Perguruan Tinggi jangka panjang, ia mengidentifikasi lima masalah besar yang dihadapi Perguruan Tinggi, yaitu:

1. Produktivitas yang rendah

2. Keterbatasan daya tampung

${ }^{3}$ Sukadji Ranuwihardjo, Kerangka Pengembangan Pendidikan Tinggi Jangka Panjang 1986-1995, (Jakarta: Dirjen Dikti, 1985), hlm. 15

${ }^{4}$ D.A. Tisna Amijaya, Kerangka Pengembangan Pendidikan Tinggi Jangka Panjang 1976-1985 (Jakarta: Dirjen Dikti, 1976), hlm. 5.
Ziyadul Kamal, MODEL PENGEMBANGAN PERGURUAN TINGGI...

3. Keterbatasan kemampuan berkembang

4. Kepincangan di antara berbagai Perguruan Tinggi

5. Distribusi yang tidak seimbang antara bidang ilmu

Untuk mengatasi lima kelemahan tersebut, D.A Tisna Amijaya mengajukan lima program besar, yaitu :

1. Peningkatan produktivitas Perguruan Tinggi

2. Peningkatan daya tampung

3. Peningkatan pelayanan kepada masyarakat

4. Peningkatan bidang keilmuan eksakta atau iptek

5. Peningkatan kemampuan berkembang.

Program ini tidak banyak berhasil, karena terdapat berbagai kendala khususnya di lingkungan Perguruan Tinggi itu sendiri dan kebijakan pendidikan nasional yang masih tetap sangat sentralistik dan kaku. Untuk menjawab tantangan dan memberikan solusi bagi lima permasalahan besar di atas, digagas sebuah konsep program pengembangan Perguruan Tinggi jangka panjang yang berbeda, yang diperkenalkan oleh Sukadji Ranuwihardjo ${ }^{5}$. Konsep yang dirumuskan tersebut adalah:

1. Peningkatan kualitas Perguruan Tinggi

2. Peningkatan produktivitas

3. Peningkatan relevansi

4. Perluasan kesempatan memperoleh pendidikan

Konsep inilah yang kemudian dirumuskan menjadi paradigma baru yang mencakup peningkatan kualitas Perguruan Tinggi secara berkelanjutan melalui peningkatan dan perbaikan kualitas manajemen, dalam hal ini otonomi, akuntabilitas dan akreditasi merupakan komponen-komponen terpenting.

Paradigma baru ini pada dasarnya bertujuan untuk merumuskan kembali peran negara dan Perguruan Tinggi, sehingga lebih memungkinkan bagi Perguruan Tinggi untuk berkembang lebih baik. Paradigma baru ini juga dimaksudkan untuk memberi panduan bagi pengembangan mekanisme baru guna memperkuat Perguruan Tinggi, seperti perencanaan atas dasar prinsip

${ }^{5}$ Sukadji , Kerangka Pengembangan Pendidikan, hlm. 7. 
A1-Fikra: Jurnal Ilmiah Keislaman, Vol. 5, No. 2, Juli-Desember 2006

desentralisasi, evaluasi berkelanjutan terhadap kualitas, dan sebagainya.

Dalam paradigma baru ini, peranan negara mengalami perubahan yang sangat signifikan dengan pengurangan peranan pemerintah. Pemerintah secara konseptual dan praktikal tidak lagi merupakan lembaga sentral yang menetapkan segala ketentuan secara rinci atau mengontrol secara terpusat seluruh gerak dan dinamika Perguruan Tinggi. Pemerintah hanya memberikan kerangka dasar, memberikan insentif agar sumber daya manusia dan keuangan dapat dialokasikan kepada prioritas-prioritas terpenting pada Perguruan Tinggi serta mendorong setiap Perguruan Tinggi meningkatkan standar kualitasnya.

Krisis moneter, ekonomi, dan politik yang terjadi di Indonesia sejak akhir 1997 sangat mempengaruhi dunia pendidikan pada seluruh jenjang dan menjadi daya dorong berkembangnya perluasan konsep paradigma baru Perguruan Tinggi, sehingga tercakup dalam konsep reformasi pendidikan nasional secara menyeluruh. Reformasi sistem pendidikan dilakukan secara menyeluruh terhadap seluruh aspek pendidikan, seperti filosofi dan kebijakan pendidikan nasional, sistem pendidikan berbasis masyarakat (community-based education), pemberdayaan guru dan tenaga kependidikan, manajemen berbasis sekolah (school-based management), implementasi paradigma baru Perguruan Tinggi dan sistem pembiayaan pendidikan ${ }^{6}$.

Daya dorong tambahan (impetus) bagi implementasi paradigma baru Perguruan Tinggi muncul dengan dikeluarkannya "World Declaration on Higher Education for the Twenty-First Century: Vision and Action" oleh UNESCO. Deklarasi UNESCO yang harus

${ }^{6}$ Santoso S. Hamidjojo, Platform Reformasi Pendidikan Nasional (Jakarta: Tim Kerja Peduli Reformasi Pendidikan Nasional, 1998), hlm. 10 dan A Malik Fadjar, Platform Reformasi Pendidikan dan Pengembangan Sumber Daya Manusia, (Jakarta: Dirjen Binbaga Islam, 1999), hlm. 25.
Ziyadul Kamal, MODEL PENGEMBANGAN PERGURUAN TINGGI.. dikembangkan oleh Perguruan Tinggi Indonesia agar relevan dengan paradigma baru tersebut, di antaranya adalah ${ }^{7}$ :

1. Tentang misi dan fungsi Perguruan Tinggi, deklarasi menegaskan bahwa misi dan nilai pokok Perguruan Tinggi adalah memberikan kontribusi kepada pembangunan yang berkelanjutan (sustainable development) dan pengembangan masyarakat secara keseluruhan

2. Memberikan berbagai kesempatan (espace ouvert) kepada para peminat untuk memperoleh pendidikan tinggi sepanjang usia

3. Memajukan, menciptakan dan menyebarkan ilmu pengetahuan melalui riset dan memberikan keahlian (expertise) yang relevan untuk membantu masyarakat umum dalam pengembangan budaya, sosial dan ekonomi, mengembangkan penelitian dalam bidang sain dan teknologi, ilmu-ilmu sosial, humaniora dan seni kreatif

4. Membantu untuk memahami, menafsirkan, memelihara, memperkuat, mengembangkan dan menyebarkan budayabudaya historis nasional, regional dan internasional dalam pluralisme dan keragaman budaya.

5. Membantu untuk melindungi dan memperkuat nilai-nilai sosial dengan menanamkan kepada generasi muda nilai-nilai yang membentuk dasar kewargaan yang demokratis (democratic citizenship)

6. Memberikan kontribusi kepada pengembangan dan peningkatan pendidikan pada seluruh jenjangnya, termasuk pelatihan para guru

Paradigma baru Perguruan Tinggi tersebut pada dasarnya bertumpu kepada tiga tungku utama, yakni ${ }^{8}$ :

1. Kemandirian lebih besar (greater autonomy) dalam pengelolaan atau otonomi. Otonomi seluas-luasnya atau setidaknya "otonomi lebih luas" adalah otonomi bukan saja dalam hal

${ }^{7}$ Isi dari Deklarasi UNESCO tentang Kebijakan Pendidikan Tinggi, yaitu Higher Education in the Twenty-First Century: Vision and Action di Paris tahun 1998

${ }^{8}$ Dirjen Dikti, Task Force Pendidikan Tinggi (Implementasi Paradigma Baru di Pendidikan Tinggi) (Jakarta: Dirjen Dikti, 1999), hlm 35. 
Al-Fikra: Jurnal Ilmiah Keislaman, Vol. 5, No. 2, Juli-Desember 2006

pengelolaan secara manajerial, tetapi juga dalam hal penentuan atau pemilihan kurikulum dalam rangka penyesuaian Perguruan Tinggi dengan dunia kerja atau kebutuhan pasar. Dalam kerangka otonomisasi ini pemerintah telah mengeluarkan Peraturan Pemerintah No. 60/1999 yang memberikan wewenang lebih luas kepada Perguruan Tinggi untuk mengembangkan dirinya. Pemerintah juga menerbitkan Peraturan Pemerintah No. 61/1999 tentang penetapan Perguruan Tinggi Negeri sebagai Badan Hukum.

2. Akuntabilitas atau tanggung urai (greater accountability), bukan hanya dalam hal pemanfaatan sumber-sumber keuangan secara lebih bertanggungjawab, tetapi juga dalam pengembangan keilmuan, kandungan pendidikan dan program-program yang diselenggarakan. Akuntabilitas ini tidak hanya kepada pemerintah sebagai pembina pendidikan atau pemberi sumber dana dan sumber daya lainnya, tetapi juga kepada masyarakat dan stake holders lainnya yang memakai dan memanfaatkan lulusan Perguruan Tinggi dan hasil pengembangan berbagai bidang ilmunya. Karena itu, di sini terkait pula akuntabilitas terhadap dunia profesi, dan masyarakat luas.

3. Jaminan lebih besar terhadap kualitas (greater quality assurance) melalui evaluasi internal (internal evaluation) yang dilakukan secara kontinyu dan berkesinambungan dan evaluasi eksternal (external evaluation), yang sekarang ini dilakukan Badan Akreditasi Nasional (BAN). BAN harus meningkatkan fungsinya dengan menentukan standar-standar yang lebih fleksibel dan dinamis atau tidak kaku, sehingga tetap memungkinkan bagi Perguruan Tinggi untuk melakukan perubahan dan penyesuaian terhadap tuntutan dan kebutuhan dunia kerja. BAN juga harus melibatkan lebih banyak unsur stakeholders dalam organisasinya, sehingga memungkinkan terjadinya "penilaian" dan "pengakuan" yang sesungguhnya dari masyarakat, yang sangat berkepentingan dengan hasil-hasil Perguruan Tinggi.

Ketiga tungku paradigma baru Perguruan Tinggi ini saling berkaitan harus diaktualisasikan secara simultan. Jika tidak maka
Ziyadul Kamal, MODEL PENGEMBANGAN PERGURUAN TINGGI.. Perguruan Tinggi tetap akan menghadapi berbagai kesulitan dalam mewujudkan fungsi-fungsi dan peranannya seperti dirumuskan dalam konsep paradigma baru Perguruan Tinggi.

\section{Perubahan IAIN menjadi UIN}

1. Konsep Perubahan IAIN menjadi UIN

“Mengapa harus berubah menjadi UIN?" Sebuah pertanyaan yang sangat amat sederhana tetapi membutuhkan jawaban yang sangat cerdas. Status sebagai IAIN hanya memberikan kewenangan dalam menangani bidang-bidang keilmuan yang beragam, namun keragaman bidang kajian itu hanyalah dalam lingkup kajian Islam. Sehingga status IAIN menjadi tidak relevan dengan keyakinan dasar Islam yang menyatakan sebagai agama universal. Konsep Islam universal ada dalam wadah Universitas Islam Negeri (UIN) yang mewujudkan integrasi dan sintesis ilmu-ilmu keislaman (agama) dengan ilmu-ilmu umum (sains) dalam sebuah bangunan peradaban Islam.

Hal inilah yang menjadi ide utama untuk mengubah status IAIN menjadi UIN, bahwa dalam Islam tidak ada pembedaan antara ilmu agama dengan ilmu sekuler. Perubahan status ini sebenarnya memberikan Universitas Islam Negeri mandat yang lebih besar dibandingkan status sebagai IAIN, yakni memberikan pemahaman kepada khalayak ramai mengenai apa itu ilmu Islam.

Sesuai dengan semangat paradigma baru Perguruan Tinggi, khususnya otonomisasi, saat ini terjadi kecenderungan visi pengembangan IAIN menjadi UIN (Universitas Islam Negeri). Gagasan dan konsep tentang pengembangan IAIN menjadi UIN bertitik tolak dari beberapa masalah yang dihadapi IAIN dalam perkembangannya selama ini. Permasalahan yang dihadapi tersebut antara lain adalah :

1. IAIN belum berperan secara optimal dalam dunia akademik, birokrasi dan masyarakat Indonesia secara keseluruhan. Di antara ketiga lingkungan ini, peran IAIN 
A1-Fikra: Jurnal Ilmiah Keislaman, Vol. 5, No. 2, Juli-Desember 2006

hanya lebih besar pada masyarakat, karena kuatnya orientasi kepada dakwah daripada pengembangan ilmu pengetahuan?.

2. Kurikulum IAIN belum mampu merespon perkembangan Iptek dan perubahan masyarakat yang semakin kompleks. Hal ini disebabkan terutama karena bidang kajian agama yang merupakan spesialiasi IAIN kurang mengalami interaksi dan reapproachement dengan ilmu-ilmu umum, bahkan masih cenderung dikotomis. Kurikulum IAIN masih terlalu berat pada ilmu-ilmu yang bersifat normatif; sedangkan ilmu-ilmu umum yang dapat mengarahkan mahasiswa kepada cara berpikir dan pendekatan yang lebih empiris dan kontekstual nampaknya masih belum memadai

\section{Konsep Keilmuan UIN}

Konsep yang seharusnya dikembangkan oleh UIN adalah konsep hierarki ilmu yang tidak memisahkan antara ilmu (sains) dan agama atau antara "ilmu umum dan "ilmu agama". Konsep ini justru memandang ilmu sebagai suatu kesatuan hierarkis yang pembentukannya didasarkan pada hierarki ontologi, hierarki epistemologi dan hierarki tujuan mempelajarinya. Secara ontologik, misalnya, hierarki ilmu tidak saja mengakui objek yang rationable dan observable tapi juga objek metafisiktransendental. Demikian juga, secara epistemologik tidak hanya mengakui metode bayani dan burbani tapi juga metode kasyfi.

Dengan konsep di atas, paradigma ilmu UIN adalah paradigma integralistik yang melakukan dediferensiasi dan deotonomisasi ilmu dan agama, dengan apa yang oleh Amin Abdullah $^{10}$ disebut sebagai reintegrasi epistemologi. Konsep

'IAIN Jakarta, Proposal Pembentukan Universitas Islam Negeri (UIN) Syarif Hidayatullah (Jakarta: IAIN Syarif Hidayatullah, 1998), hlm. 8

${ }^{10}$ Amin Abdullah, Menyatukan Kembali Ilmu-Ilmu Agama dan Umum: Upaya Mempertemukan Epistemologi Islam dan Umum, (Yogyakarta: Suka Press, 2003), hlm. 3 .
Ziyadul Kamal, MODEL PENGEMBANGAN PERGURUAN TINGGI. . reintegrasi epistimologi ini kemudian dikembangkan oleh Amin dalam skema "Horizon jaring laba-laba keilmuan teoantroposentrik-integralistik Universitas Islam Negeri".

Dengan konsep seperti itu, paling tidak ada tiga jenis keilmuan paradigma integralistik yang berkemungkinan dikembangkan dan menjadi keunikan UIN, yaitu:

Pertama, ilmu-ilmu agama. Pengembangannya bisa dilakukan dengan lebih intens menggunakan pendekatan ilmuilmu sosial dan humaniora seperti antropologi, sosiologi, psikologi dan filsafat dengan berbagai teori dan pendekatan yang ditawarkan, seperti yang telah dilakukan oleh M. Arkoun atau Al-Jabiri.

Kedua, ilmu-ilmu sosial dan humaniora. Kemungkinan pengembangannya terbuka lebar karena, menurut Thomas Kuhn, ilmu yang ada saat ini dibangun di atas landasan paradigma-paradigma tertentu. Misal paradigma behavioristik, paradigma positivistik, paradigma Marxis, paradigma kritis dan sebagainya. Dengan demikian, terbuka kemungkinan mengembangkan paradigma alternatif seperti paradigma integralistik (Islam). Satu contoh menarik adalah pengembangan Ekonomi Syariah.

Ketiga, ilmu-ilmu alam atau natural science baik ilmu murni (pure science) seperti biologi, kimia, fisika dan astronomi, maupun ilmu terapan (applied science) seperti kedokteran, farmasi, pertanian dan lain-lain. Dulu, ilmu ini mengklaim diri sebagai ilmu netral yang tidak memerlukan etika dan moral. Akan tetapi dalam perkembangannya, ilmu alam ini tidak mampu menjawab persoalan-persoalannya sendiri.

\section{Model Perubahan IAIN menjadi UIN}

Berdasarkan konsep keilmuan tersebut, pengembangan IAIN menjadi Universitas Islam Negeri (UIN) mempunyai alasan yang cukup kuat. Namun demikian, masih terdapat cukup banyak kendala pokok yang harus diatasi, khususnya legal constraints yang berkaitan dengan Undang-undang Sistem 
Al-Fikra: Jurnal Ilmiah Keislaman, Vol. 5, No. 2, Juli-Desember 2006

Pendidikan Nasional (UUSPN) dan Departemen Pendidikan Nasional (Depdiknas).

Penerbitan PP 60/1999 mengenai kewenangan Perguruan Tinggi, juga belum cukup reformis untuk memungkinkan perubahan IAIN menjadi UIN, karena itu dalam kerangka transformasi IAIN kepada UIN, setidaknya ada dua opsi yang dapat dipilih. Kedua opsi itu masing-masingnya mempunyai kekuatan dan kelemahan.

Opsi Pertama, langsung mengubah atau mentransformasikan IAIN yang mungkin dipandang "cukup siap", terutama dari segi SDM dan lingkungan akademik, untuk menjadi UIN. Transformasi seperti ini melibatkan perubahan/penyesuaian atau peningkatan fakultas-fakultas yang ada sekarang dan pembentukan fakultas-fakultas baru sesuai dengan konsep dan kerangka UIN. Langkah transformasi seperti ini mengandung beberapa masalah khususnya dalam penambahan prasarana, sarana dan SDM dalam bidang keilmuan tertentu, khususnya "ilmu umum".

Opsi Kedua, mendirikan atau membentuk jurusan-jurusan dan fakultas-fakultas baru dalam institusi IAIN sekarang sehingga secara substantif sesuai dengan kerangka UIN.

Konsep dan kerangka pengembangan UIN ataupun IAIN memerlukan model tertentu, baik dilihat secara epistimologis keilmuan maupun kelembagaan. Model tersebut diperlukan untuk menjaga agar bidang-bidang agama yang selama ini menjadi karakter IAIN tidak terkesampingkan atau termarjinalkan, karena terdapat beberapa konsep dan kerangka pembentukan UIN yang diharapkan bisa menjadi kemurnian karakter UIN, yaitu ${ }^{11}$ :

1. Model Universitas Al-Azhar

Pada model ini, fakultas-fakultas agama berdiri berdampingan dengan fakultas-fakultas umum. Fakultas-

${ }^{11}$ Azyumardi Azra, LAIN ditengah Paradigma Baru Perguruan Tinggi, (Jakarta: Dirjen Kelembagaan Agama Islam), hlm. 8.
Ziyadul Kamal, MODEL PENGEMBANGAN PERGURUAN TINGGI.. fakultas ini cenderung terpisah satu sama lain, walaupun tetap di bawah satu payung. Kecenderungan dari model ini adalah bahwa fakultas-fakultas umum menjadi fakultasfakultas favorit, sementara fakultas-fakultas agama menjadi "fakultas-fakultas pilihan kedua", untuk tidak menyebut "periferal".

2. Model Perguruan Tinggi Agama Islam Swasta (PTAIS)

PTAIS mempunyai fakultas agama yang berdiri terpisah. Dalam model ini, fakultas-fakultas umum berdampingan dengan fakultas agama yang terdiri dari beberapa jurusan, seperti jurusan tarbiyah, jurusan syari'ah (yang sebelumnya dalam institusi IAIN merupakan fakultas-fakultas tersendiri). Dalam model ini, subyek-subyek agama bisa menjadi periferal, karena hanya ada satu fakultas agama.

3. Model Universiti Islam Antarbangsa (UIA)" Kuala Lumpur Dalam model ini ilmu-ilmu dibagi menjadi "revealed knowledge," ilmu-ilmu kewahyuan, yang memunculkan fakultas/jurusan agama; dan "acquired knowledge", ilmu perolehan, yang selanjutnya diterjemahkan menjadi fakultas-fakultas atau jurusan-jurusan umum, seperti teknik, kedokteran, ekonomi, psikologi, antropologi, dan sebagainya. Bidang-bidang ini selain "diislamisasikan", ketika dijabarkan ke dalam kurikulum, juga dilengkapi dengan subyek-subyek keislaman dan lainnya yang berkaitan.

\section{Universitas Islam Negeri}

Beberapa IAIN dan STAIN yang telah berubah status menjadi Universitas Islam Negeri (UIN), adalah:

1. UIN Syarif Hidayatullah ${ }^{12}$

IAIN Syarif Hidayatullah berubah menjadi UIN (Universitas Islam Negeri) Syarif Hidayatullah Jakarta berdasarkan

${ }^{12}$ www.uin-jkt.ac.id 
Al-Fikra: Jurnal Ilmiah Keislaman, Vol. 5, No. 2, Juli-Desember 2006

Keputusan Presiden (Keppres) No 31 tanggal 20 Mei 2002.

UIN Jakarta diresmikan oleh Wakil Presiden (saat itu) Hamzah Haz pada tanggal 08 Juni 2002

2. UIN Sunan Kalijaga

Keputusan Presiden No 50 tanggal 21 Juni 2004 tentang Perubahan Institut Agama Islam Negeri Sunan Kalijaga Yogyakarta menjadi Universitas Islam Negeri Sunan Kalijaga Yogyakarta

3. UIN Malang

Universitas Islam Negeri (UIN) Malang adalah salah satu perguruan tinggi Islam di Indonesia yang berdiri berdasarkan Surat Keputusan Presiden Republik Indonesia Nomor 50 Tahun 2004 tanggal 21 Juni 2004. Surat Keputusan tersebut diterbitkan menyusul Surat Keputusan Bersama (SKB) Menteri Pendidikan Nasional dan Menteri Agama Republik Indonesia Nomor 1/0/SKB/2004 dan Nomor ND/B.V/I/Hk.00.1/058/04 tanggal 23 Januari 2004 tentang Perubahan Bentuk Sekolah Tinggi Agama Islam Negeri Malang menjadi Universitas Islam Negeri Malang

4. UIN Alauddin Makasar

IAIN Alauddin Makasar resmi menjadi UIN Alauddin Makasar berdasarkan Surat Keputusan Menteri Pendidikan Nasional No 179/MPN/KL/2004 tanggal 10 Desember 2004

5. UIN Sunan Gunung Djati

Perubahan IAIN SGD menjadi UIN SGD bersamaan dengan UIN Sunan Gunung Djati berdasarkan persetujuan dari Mendiknas dengan Surat Keputusan Menteri Agama No. 179/MPN/KL/2004 tanggal 10 Desember 2004

6. UIN Sultan Syarif Kasim

IAIN Susqa yang didirikan pada tanggal 9 September 1970 berdasarkan Surat Keputusan Menteri Agama No. 194 tahun 1970 telah resmi berubah menjadi universitas berdasarkan Peraturan Presiden RI Nomor 2 Tahun 2005 tanggal 4 Januari 2005 tentang Perubahan Institut Agama
Ziyadul Kamal, MODEL PENGEMBANGAN PERGURUAN TINGGI..

Islam Negeri Sultan Syarif Qasim Pekanbaru menjadi Universitas Islam Negeri Sultan Syarif Kasim Riau dan diresmikan pada tanggal 9 Februari 2005 oleh Bapak Presiden RI, Dr. H. Susilo Bambang Yudhoyono di Pekanbaru.

\section{Profil UIN Suska Riau ${ }^{13}$}

Pada awal berdirinya, IAIN Susqa hanya memiliki tiga fakultas, yaitu Fakultas Tarbiyah, Fakultas Syariah, dan Fakultas Ushuluddin. Pada masa selanjutnya IAIN Susqa terus berkembang dengan bertambahnya jumlah fakultas dan berbagai sarana lainnya, seiring dengan upaya peningkatan status IAIN Susqa menjadi UIN Suska Riau.

Saat ini UIN Suska Riau memiliki tujuh fakultas dan satu Program Pascasarjana. Fakultas dan program tersebut adalah Tarbiyah, Syari'ah, Ushuluddin, Dakwah dan Ilmu Komunikasi, Psikologi, Sains dan Teknologi, Ekonomi dan Ilmu Sosial, Peternakan dan Pascasarjana.

Melalui Tridharma Perguruan Tinggi, lembaga ini diharapkan dapat melahirkan sarjana dan cendikiawan Muslim yang mampu mendalami dan mengembangkan ilmu pengetahuan, teknologi, dan seni yang terintegrasi dengan Islam, guna disumbangkan kepada agama, bangsa, dan negara melalui peran sertanya dalam pembangunan nasional, khususnya masyarakat Riau.

\section{Visi UIN Suska}

Mewujudkan Universitas Islam Negeri sebagai lembaga pendidikan tinggi utama yang mengembangkan ajaran Islam, ilmu pengetahuan, teknologi, dan seni secara integral di kawasan Asia Tenggara Tahun 2013. 
Al-Fikra: Jurnal Ilmiah Keislaman, Vol. 5, No. 2, Juli-Desember 2006

Misi UIN Suska

1. Melaksanakan pendidikan dan pengajaran untuk melahirkan sumberdaya manusia yang berkualitas secara akademik dan profesional serta memiliki integrasi pribadi sebagai sarjana muslim.

2. Melaksanakan penelitian dan pengkajian untuk mengembangkan lmu pengetahuan, teknologi, dan seni dengan menggunakan paradigma Islami.

3. Memanfaatkan ilmu pengetahuan, teknologi, dan seni sebagai pengabdian kepada masyarakat dengan menggunakan paradigma Islami.

4. Menyiapkan sumberdaya manusia serta sarana dan prasarana untuk menunjang kelancaran pelaksanaan Tridharma Perguruan Tinggi.

\section{Tujuan UIN Suska}

1. Menyiapkan peserta didik yang berakhlak mulia menjadi anggota masyarakat yang memiliki kemampuan dan keunggulan akademik dan/atau profesional yang dapat menerapkan, mengembangkan, dan/atau menciptakan ilmu agama Islam, teknologi, seni, dan/atau ilmu lain yang terkait.

2. Menggali, mengembangkan, dan menyebarluaskan ilmu agama Islam, teknologi, seni, dan/atau ilmu lain yang terkait serta mengupayakan penggunaannya untuk meningkatkan martabat dan taraf kehidupan masyarakat serta memperkaya kebudayaan nasional.

\section{Karakteristik UIN Suska}

1. Pengembangan berbagai cabang ilmu pengetahuan dengan pendekatan religius sehingga nilai-nilai Islam menjadi roh bagi setiap cabang ilmu pengetahuan

2. Pengembangan paradigma ilmu yang memberi penekanan pada rasa iman dan tauhid (belief affection)
Ziyadul Kamal, MODEL PENGEMBANGAN PERGURUAN TINGGI. .

3. Penyelenggaraan beberapa disiplin ilmu untuk mencapai standar kompetensi ilmu-ilmu keislaman yang memperkuat domain akidah, ibadah, akhlak, dan muamalah Islamiyah, dan penerapan prinsip Islam dalam Disiplin Ilmu (IDI) sebagai upaya riil mewujudkan integrasi ilmu dengan Islam.

4. Pembinaan dan pengembangan lingkungan yang madani sesuai dengan nilai-nilai Islam.

5. Perwujudan keunggulan akademik dan profesionalisme yang didasarkan pada moral keagamaan dalam kehidupan kampus di kalangan sivitas akademika

6. Mengembangkan studi Regional Islam Asia Tenggara dan Tamaddun Melayu sebagai pola ilmiah pokok

\section{Tantangan UIN Suska}

Sebelum IAIN Susqa berubah menjadi UIN Suska, fakultasfakultas agama yang ada menjadi favorit untuk menuntut ilmu. Namun setelah IAIN Susqa berubah menjadi UIN Suska, ketertarikan masyarakat berkurang bahkan cenderung menghilang. Masyarakat berubah arah, cenderung memilih fakultas-fakultas baru yang ditawarkan oleh UIN Suska.

Keadaan seperti ini tidak bisa dibiarkan terus menerus jika menginginkan keberadaan UIN Suska sebagai salah satu pusat kajian Islam, terutama di provinsi Riau tetap eksis. UIN Suska harus segera mengambil tindakan untuk mengatasi keterpurukan tersebut.

\section{Analisa Perubahan IAIN menjadi UIN}

Perubahan sebuah institut menjadi universitas harus selaras dengan kebijaksanaan pemerintah tentang pendidikan tinggi untuk memberikan prioritas pada pengembangan jurusan-jurusan dan fakultas-fakultas eksakta. Dan perubahan tersebut harus dimulai dengan penyiapan SDM dalam bidang-bidang yang akan dikembangkan, daripada perubahan institusional. Konsep dan kerangka ini menjadikan IAIN mendapat mandat lebih luas (IAIN 
Al-Fikra: Jurnal Ilmiah Keislaman, Vol. 5, No. 2, Juli-Desember 2006 with wider mandate). Alternatif ini mungkin lebih "realistis" dari segi penyiapan prasarana, sarana dan sumber daya.

Salah satu perubahan yang paling tampak dari pengembangan IAIN menjadi UIN adalah penambahan fakultas serta perluasan disiplin dan bidang kajian. Fakultas yang sebelumnya hanya terkait dengan disiplin keilmuan dasar Islam kemudian ditambah dengan beberapa fakultas yang mengkaji disiplin keilmuan yang tidak berkaitan langsung dengan disiplin dasar Islam. Namun satu hal yang perlu diingat adalah bahwasanya dalam konteks UIN tidak membedakan adanya fakultas agama dan fakultas umum.

Model ideal perubahan IAIN menjadi UIN adalah model UIN yang dibuktikan dengan program pengembangan struktur keilmuan UIN itu sendiri, yakni semua mahasiswa, baik jurusan agama maupun jurusan umum harus Mata Kuliah Ciri Khusus (MKCK) UIN meliputi Studi Al-Qur'an, Studi Hadits, Studi Fiqh, Tasawuf, Teologi, Bahasa Arab dan lain-lain, sehingga diharapkan lulusan UIN akan menyandang gelar "Ulama yang Intelek Professional dan Intelek Profesional yang Ulama".

Lebih daripada itu, perwujudan UIN merupakan tahap lebih lanjut dari pengarusutamaan (mainstreaming) lembaga pendidikan tinggi Islam. Pengarusutamaan itu sebenarnya telah dimulai ketika dalam UU Sisdiknas 1999, madrasah diakui dan dinyatakan sebagai equivalen dengan sekolah umum. Dari segi ini, kemunculan UIN merupakan konsekuensi logis dari mainstreaming yang sudah berlangsung pada tingkat madrasah.

Dengan adanya mainstreaming pendidikan tinggi Islam, terbukalah peluang bagi UIN untuk berkompetisi dengan perguruan tinggi lain di Tanah Air; tidak hanya untuk mencapai ekspektasi keunggulan akademis, tetapi juga sekaligus sebagai ekspektasi sosial, agar dapat berperan lebih luas dan kontribusi lebih besar bagi kemajuan bangsa dan negara.

Bagi UIN Suska, untuk menghadapi tantangan yang ada sekarang ini, penulis menawarkan beberapa alternatif tindakan, antara lain:

a. Mengadopsi kebijakan UIN Syarif Hidayatullah, yaitu membuka

Fakultas Tadris yang kurikulumnya berdasarkan kajian Islam,
Ziyadul Kamal, MODEL PENGEMBANGAN PERGURUAN TINGGI...

dimana bahasa pengantar perkuliahan menggunakan bahasa arab dan mengkaji kitab arab gundul.

b. Mengadopsi kebijakan UIN Malang, yaitu mengasmarakan mahasiswa baru baik mahasiswa yang berasal dari fakultas agama maupun fakultas umum untuk memperdalam kajian Islam, termasuk peningkatan kemampuan berbahasa arab.

c. Mendirikan lembaga-lembaga yang mendukung fakultas yang telah ada, misalnya adanya Fakultas Syariah didukung dengan pendirian lembaga Bantuan Hukum Islam sehingga ilmu yang ada langsung terlihat penerapan dan manfaatnya bagi masyarakat. Fakultas'Tarbiyah, seperti yang dilakukan UIN Yogya yang mempunyai MAN LAB. Siswa yang lulus dari MAN LAB diarahkan dan diharapkan akan melanjutkan pendidikan ke Fakultas Tarbiyah UIN sehingga Fakultas Tarbiyah UIN tidak akan kehilangan peminatnya.

\section{Penutup}

Perubahan IAIN menjadi UIN haruslah menjadikan UIN sebagai suatu Perguruan Tinggi yang berbeda dengan Perguruan Tinggi Umum dan bahkan berbeda dengan Perguruan Tinggi Islam yang telah ada sekarang. UIN haruslah memiliki karakteristik tersendiri yang membedakannya dengan Perguruan Tinggi Umum. Bahkan juga tidak harus sama dengan dengan Universitas Islam sejenis yang sudah lama berkembang.

Kehadiran UIN harus dapat memberikan banyak peran dan inovasi baru, atau dengan kata lain UIN harus berani tampil beda dibandingkan dengan universitas lain yang selama ini masih dalam kompetensi institusi keilmuan yang dapat dipertanggungjawabkan secara akademik dan moral. Berani tampil beda merupakan tantangan, sekaligus merupakan kesempatan mencari peluangpeluang baru sehingga peran-peran yang dimainkan akan terasa baru dan selama ini belum tergarap secara maksimal oleh perguruan Tinggi yang sudah ada.

Kurikulum yang dikembangkan selama ini di Perguruan Tinggi Islam masih diwarnai dengan adanya dikotomisasi ilmu, hal 
Al-Fikra: Jurnal Ilmiah Keislaman, Vol. 5, No. 2, Juli-Desember 2006

ini dibuktikan masing-masing keilmuan (baca; mata kuliah) masih berdiri sendiri-sendiri. Harapan dengan lahirnya UIN adalah dalam kurikulum tidak ada lagi pemisahan antara ilmu umum dan ilmu agama, UIN harus mampu mengintegrasikan ajaran Islam ke dalam setiap mata kuliah yang menjadi lahan garapannya, UIN harus mampu mengaitkan setiap materi kuliahnya dengan ruh dan pesanpesan Islam, sehingga UIN diharapkan dapat mencetak sarjana muslim yang memiliki dua keunggulan, yakni keunggulan di bidang Sains dan Teknologi sekaligus keunggulan di bidang wawasan keislaman.

\section{Bibliografi}

Abdullah, Amin, Menyatukan Kembali Ilmu-Ilmu Agama dan Umum: Upaya Mempertemukan Epistemologi Islam dan Umum, (Yogyakarta: Suka Press, 2003)

Amijaya, D.A Tisna, Kerangka Pengembangan Pendidikan Tinggi Jangka Panjang 1976-1985 (Jakarta: Dirjen Dikti, 1976)

Azra, Azyumardi, LAIN ditengah Paradigma Baru Perguruan Tinggi, (Jakarta: Dirjen Kelembagaan Agama Islam, 2002)

Dirjen Dikti, Task Force Pendidikan Tinggi (Implementasi Paradigma Baru di Pendidikan Tinggi) (Jakarta: Dirjen Dikti, 1999)

Fadjar, A. Malik, Platform Reformasi Pendidikan dan Pengembangan Sumber Daya Manusia (Jakarta: Dirjrn Binbaga Islam, 1999)

Hamidjojo, S. Santoso, Platform Reformasi Pendidikan Nasional (Jakarta: Tim Kerja Peduli Reformasi Pendidikan Nasional, 1998)

IAIN Jakarta, Proposal Pembentukan Universitas Islam Negeri (UIN) Syarif Hidayatullah (Jakarta: IAIN Syarif Hidayatullah, 1998)
Ziyadul Kamal, MODEL PENGEMBANGAN PERGURUAN TINGGI.. Ranuwihardjo, Sukadji, Kerangka Pengembangan Pendidikan Tinggi Jangka Panjang 1986-1995, (Jakarta: Dirjen Dikti, 1985)

UNESCO, Higher Education in the Twenty-First Century: Vision and Action (Paris: UNESCO, 1998).

Wiratmo, Masykur, "Prospek PTAI di Indonesia (Mengamati Kecendrungan Perubahan ke Arah UIN)" (Jakarta: Swara Ditpertais, 2005), No. 24 Th, III, 03 Februari 2005 